\title{
Enzyme Encapsulation by Static Mixer Method for Hydrolysis of Lactose
}

\author{
Hui lan Tan, Monwar Hossain ${ }^{*}$ and Lu Zhang\#
}

\author{
Department of Chemical \& Petroleum Engineering, United Arab Emirates University, P.O. Box 17555, Al Ain, \\ $U A E$
}

\begin{abstract}
Enzyme immobilisation has been intensively investigated due to its advantages such as enzyme recovery, reusability and improved stability over a wide range of $\mathrm{pH}$ and temperatures. The encapsulation of $\beta$-galactosidase in $\mathrm{K}$ carrageenan is presented in this report for potential application in dairy industry. The immobilisation was carried out by emulsifying oil and $\mathrm{k}$-carrageenan with a static mixer device. This is a new approach and has the advantage of producing smaller beads (e.g. smaller than $100 \mu \mathrm{m}$ size) which can be used in continuous processing. The main factors tested were the total flow rate through the static mixer $\left(Q_{t}\right.$, in the range $\left.220-440 \mathrm{ml} / \mathrm{min}\right)$ and $\mathrm{k}$-carrageenan to oil volumetric fraction $(\varepsilon$, in the range $0.05-0.2)$. The average bead sizes obtained were in the range of $19-52 \mu \mathrm{m}$, with smaller sizes obtained with an increase of $Q_{t}$. The bead sizes decreased with (i) the decrease in emulsified droplets coalescence and oil inclusion in the beads and (ii) with the decrease in the values of $W_{\text {top }}$ (defined by the weight percentage of beads found underneath the oil layer).

The bead performance was tested using lactose and 2-nitrophenyl- $\beta$-galactopyranoside (ONPG) and the kinetic parameters, lactose conversion and stability were determined at the optimum conditions. The attained optimum $\mathrm{pH}$ and temperature were 7 (similar to free enzyme) and $21^{\circ} \mathrm{C}$, respectively. The encapsulated $\beta$-galactosidase tested at optimum conditions in $5 \%(\mathrm{w} / \mathrm{v})$ lactose solution was able to convert $76.47 \%$ of lactose after six days. These findings contribute to the further understanding of the encapsulation technique and demonstrates the potential of using $\mathrm{k}$ carrageenan as an encapsulation material for $\beta$-galactosidase.
\end{abstract}

Keywords: Static mixer, Emulsion, $\beta$-galactosidase, k-Carrageenan, microencapsulation.

\section{INTRODUCTION}

Approximately $70 \%$ of the world's adult population are lactose intolerant [1] although 370 million tons of milk is produced worldwide. This creates a huge demand for lactose reduced dairy products. Industrially, 3.2 million tons of lactose dissolved in whey are accumulated each year in the world, half of which is utilised but the other half amount is disposed as waste. The lactose in this waste needs to be broken down as it poses an environmental threat due to its low biodegradability [2]. Due to these problems faced by the dairy industry the need for improving the lactose hydrolysis process is important.

To hydrolyse the lactose, two methods have been proposed in the literature. The first method is to perform hydrolysis with acids at high temperature (150 ${ }^{\circ} \mathrm{C}$ ), which is not favourable in the food industry because of undesirable effects on the product. The second method is by an enzyme catalysed reaction at a mild $\mathrm{pH}$ and temperature $\left(4-40{ }^{\circ} \mathrm{C}\right)$ [3]. For the enzymatic conversion of lactose, $\beta$-galactosidase from Kluyveromyces fragilis or commonly known as lactase

*Address corresponding to this author at the Department of Chemical \& Petroleum Engineering, United Arab Emirates University, P.O. Box 17555, Al Ain, UAE; Tel: +971-3-7135315; Fax: +971-3-7624262;

E-mail: mmonwar@uaeu.ac.ae

\#Present address: Fonterra, Palmerston North, New Zealand;

E-mail: Lu.Zhang@auckland.ac.nz is chosen [4,5]. $\beta$-galactosidase works better at the natural temperature and $\mathrm{pH}$ of milk. It can retain activity at low temperature up to $4{ }^{\circ} \mathrm{C}[6]$ and is also recognised as safe (GRAS) [7]. However, $\beta$-galactosidase is relatively expensive and continuously degrades during storage. So a method such as encapsulation of enzyme is required to protect the $\beta$-galactosidase activity in vitro and in vivo. The encapsulation process is mild and has advantages for enzymatic process [8, 9], can be re-used several times [10] and in the spherical form has special hydrodynamic properties suitable for bioreactors [9].

Droplet and emulsification methods are commonly used to produce spherical gel beads. The beads are formed by passing the encapsulation material/enzyme mixture solution through a needle or orifice [9, 11]. Extensive research has been carried out to improve and optimize the process [11].

The concept of emulsification is to form an emulsion by mixing encapsulation/enzyme solution in a nonaqueous phase typically vegetable oil [11]. Emulsification is generally carried out in a turbine stirred reactor [12]. An alternative approach is to replace the stirred tank with a static mixer which has the potential for continuous processing with lower cost. This technique is better with bead sizes below $500 \mu \mathrm{m}$, it is easier to control the process and has less scale-up issues [13-16].

(C) 2012 Lifescience Global 
$\mathrm{K}$-Carrageenan, a natural bioplolymer, as an encapsulating material has been extensively used in food products for almost 600 years [17]. Gelation can be initiated by the reduction of temperature or in the presence of ions, such as $\mathrm{K}+, \mathrm{Rb}+, \mathrm{Cs}+, \mathrm{NH} 4+[11$, 17]. There has been limited study on the use of static mixer for microencapsulation [12-14]. Study carried out by Belyaeva et al. [12] suggested procedures and feasibility region for forming discrete and spherical beads. The increase of elements in the static mixer and total volume flow rate in the static mixer have been found to affect the bead size with no effect on size distribution [13, 14].

In another study by Decamps et al. [15], it was concluded that an increase in static mixer diameter results in the increase of average bead diameter and size distribution. To avoid this effect the use of multiple medium size static mixers in parallel were suggested.

The main objectives of the present work were (i) to optimise the encapsulation of $\beta$-galactoside by emulsification with the utilisation of a static mixer, (ii) to investigate the factors influencing the bead production and (iii) to analyse the bead performance in a batch enzyme reactor. The encapsulation method used in the present study is similar to those reported in the literature $[12,15]$.

\section{MATERIALS AND METHODS}

\subsection{Chemicals}

2-Nitrophenyl $\beta$-D-galactopyranoside (ONPG), $\alpha$ lactose monohydrate (reagent grade), $\beta$-galactosidase (from Kluyveromyces lactis), potassium chloride (reagent grade), chitosan (from crab shells practical grade) and Glucose (GO) assay kit- all were obtained from Sigma-Aldrich, MO, USA. Commercial peanut oil is from AMCO New Zealand. All other reagents were of analytical grade.

\section{2. $k$-Carrageenan and $\beta$-Galactosidase Solution Preparation}

$10 \mathrm{~mL}$ of 750 units $/ \mathrm{mL} \beta$-galactosidase solution was prepared. The enzymes were diluted at a factor of 4 in $0.1 \mathrm{M}$ dibasic sodium phosphate-citric acid buffer $(\mathrm{pH}$ 6.5) containing $3 \mathrm{mM}$ of $\mathrm{MgCl}_{2}$.

$1.5 \%(\mathrm{w} / \mathrm{w}) \mathrm{K}$-carrageenan solution is used in the present study. $1.5 \mathrm{~g}$ of $\mathrm{k}$-carrageenan powder was added into $90 \mathrm{~mL}$ of $0.01 \mathrm{M} \mathrm{KCl}$. The suspended solution was stirred and heated to $70^{\circ} \mathrm{C}$. It was held for 20 minutes to completely dissolve the $\mathrm{K}$-carrageenan and cooled down to the $45{ }^{\circ} \mathrm{C}$ or $50^{\circ} \mathrm{C}$ for bead production. $10 \mathrm{~mL}$ of $\beta$-galactosidase solution was then mixed into the $\mathrm{k}$-carrageenan solution just before the start of bead production.

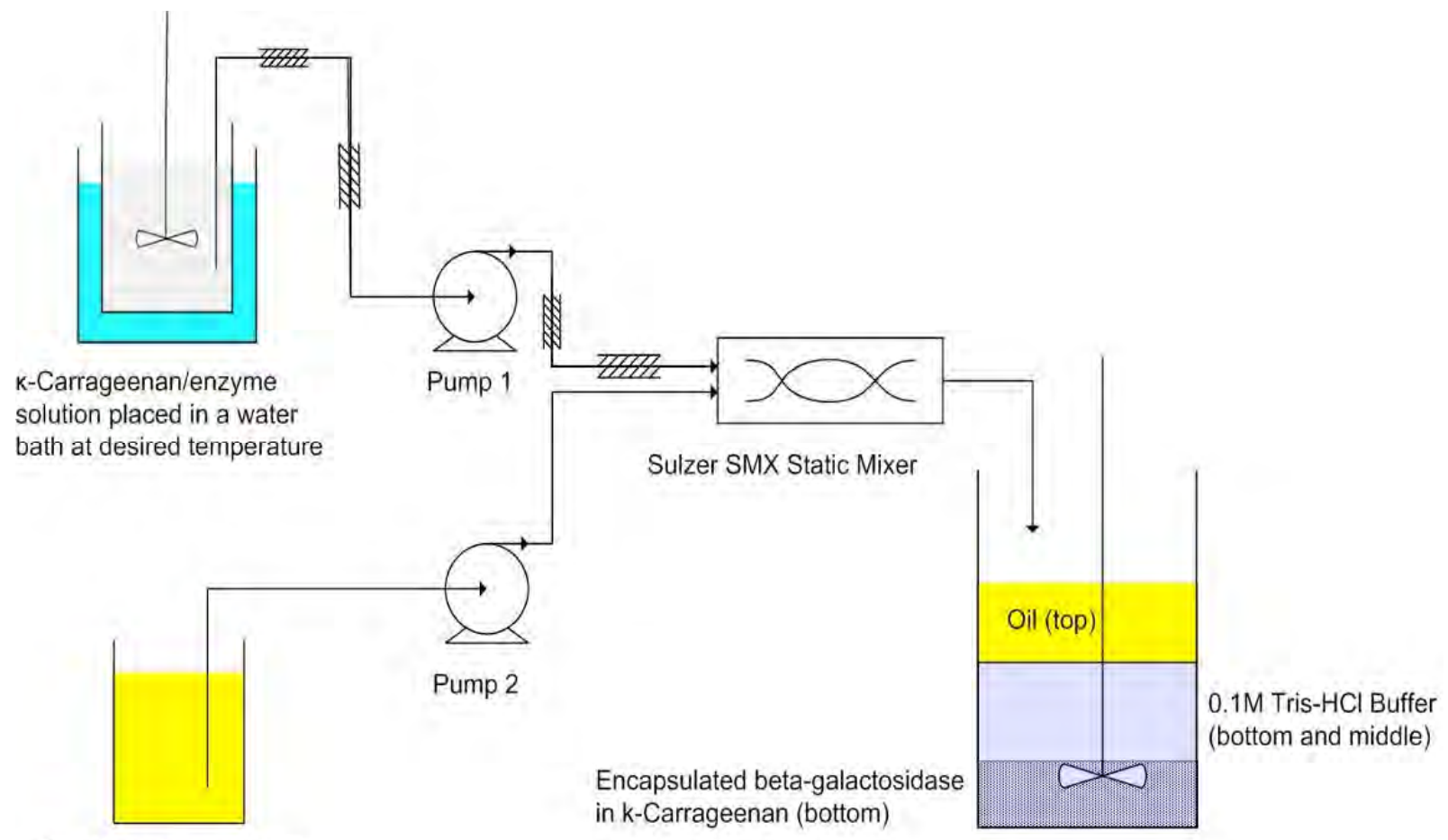

Oil at room temperature

Figure 1: A schematic of the experimental setup for $\beta$-galactosidase bead production. 


\section{3. $\beta$-Galactosidase Bead Production by Static Mixer}

The prepared $\mathrm{k}$-carrageenan/enzyme solution was placed in the water bath with continuous agitation (overhead stirrer at low rpm) (Figure 1) at a temperature of $45^{\circ} \mathrm{C}$ or $50^{\circ} \mathrm{C}$. Peanut oil was used as the continuous phase and held at $21^{\circ} \mathrm{C}$ (room temperature). The process was started by feeding the static mixer (Sulzer Chemtech Ltd, Winterthurn, Switzerland) with $\mathrm{k}$-carrageenan/enzyme solution and oil at the required flow rate. The static mixer consisted of four elements with $6 \mathrm{~mm}$ diameter. The total flow rate through the static mixer $\left(Q_{t}\right)$ was varied at 220 , 240,420 and $440 \mathrm{~mL} / \mathrm{min}$ which corresponded to a $\mathrm{K}$ carrageenan to oil volumetric fraction $(\varepsilon)$ of $0.1,0.2$, 0.05 and 0.1 , respectively.

The resulting liquid-liquid emulsion was collected in a stirred beaker containing $0.1 \mathrm{~mol}$ Tris- $\mathrm{HCl}$ buffer with $0.2 \mathrm{~mol} \mathrm{KCl}(\mathrm{pH} 8.1)$ at $4^{\circ} \mathrm{C}$. It was then left at room temperature for two hours to allow the formed gel beads to harden and transfer to the aqueous phase. After two hours, the oil was decanted and the beads were recovered from the Tris- $\mathrm{HCl}$ buffer by vacuum filtration through a $30 \mu \mathrm{m}$ mesh and filter paper. During the separation, the beads were rinsed with $1 \%(\mathrm{v} / \mathrm{v})$ Tween 80 in $0.2 \mathrm{M} \mathrm{KCl}$ solution and $0.1 \mathrm{M}$ Tris- $\mathrm{HCl}$ buffer.

The retrieved beads were gently stirred in $0.2 \%$ $(\mathrm{w} / \mathrm{v})$ chitosan solution $(\mathrm{pH} 6)$ at room temperature for 30 minutes. The beads were then separated using the same method as stated above. The damp beads were stored at $4^{\circ} \mathrm{C}$ without medium for further analysis.

\subsection{Characterisation of $\beta$-Galactosidase Beads}

A certain amount of beads were placed onto a glass slide under a cover slip and viewed using an optical microscope (Nikon MULTIZOOM AZ100, Japan). Images were taken and analysed to obtain an average bead size. "Image J" was used to obtain the diameter measurements.

The beads were also observed with scanning electron microscopy (SEM, Philips XL30S SEM, Amsterdam, Netherlands). $20 \mu \mathrm{L}$ of the dispersed beads was placed on a cover slip mounted on metal holders using double-sided adhesive tape. The samples were air dried overnight before coating them with platinum. It was done with a coating device (Polaron SC7640 Sputter Coater, East Sussex, UK) at 5 to $10 \mathrm{~mA}, 1.1 \mathrm{kV}$. Images were captured for analysis.

\section{5. $\beta$-Galactosidase Activity Assays}

The enzyme activity was assayed using an artificial substrate, 2-nitrophenyl- $\beta$-galactopyranoside (ONPG), and the natural substrate, lactose. The yellow colour developed due to the formation of ONP was measured at $420 \mathrm{~nm}$ with a diode-array spectrophotometer. One unit of enzyme activity with ONPG substrate (OAU) is defined as the amount of enzyme which catalyses the conversion of $1 \mathrm{mM}$ of ONPG to ONP per minute at testing conditions.

For lactose related tests, $1 \mathrm{~g}$ of damp beads was tested with $10 \mathrm{~mL}$ of $5 \%(\mathrm{w} / \mathrm{v})$ a-lactose solution (dissolved in $0.1 \mathrm{M}$ sodium phosphate buffer) at room temperature and $\mathrm{pH} 7.1 \mathrm{~mL}$ of sample was withdrawn at different times and filtered through a $30 \mu \mathrm{m}$ mesh into $1 \mathrm{~mL}$ of double deionised (D-D) water. It was placed in boiling water $\left(\approx 100^{\circ} \mathrm{C}\right)$ for 10 minutes to deactivate any enzyme. The samples were then diluted with D-D water and tested with the glucose assay kit. The glucose concentration was measured using a glucose (GO) assay kit. The pink colour developed was measured at $540 \mathrm{~nm}$ with a diode-array spectrophotometer. One unit of enzyme activity with $\alpha$ lactose (LAU) is defined as the amount of enzyme which catalyses the conversion of $1 \mathrm{mM}$ of lactose to glucose per minute at testing conditions.

\subsection{Operational Stability Test}

The encapsulated $\beta$-galactosidase was tested for reusability with ONPG substrate. This test was done by recovering the beads after use and rinsing it with $0.1 \mathrm{M}$ Tris-HCL buffer. The beads were then suspended into a fresh substrate and tested for enzyme activity. This was repeated until the enzyme lost at least $50 \%$ of its activity.

\subsection{Storage Stability Test}

The residual activity of the encapsulated enzyme stored at $4^{\circ} \mathrm{C}$ without buffer was tested using ONPG substrate. The storage times were 1, 2, 3 and 4 weeks after the beads were made.

\subsection{Long Lactose Hydrolysis Test}

The beads were tested with $5 \%(\mathrm{w} / \mathrm{v})$ lactose solution $\mathrm{pH} 7$ at R.T. and $4{ }^{\circ} \mathrm{C}$ for up to 6 days. The apparatus used for this test were autoclaved $\left(121^{\circ} \mathrm{C}\right.$, 15 minutes) to minimise microbial growth. $0.1 \%$ sodium azide was also added into the lactose solution for the same reason. 


\subsection{Optimum Conditions}

The activity of $\beta$-galactosidase beads was determined using ONPG substrate at temperatures of $21^{\circ} \mathrm{C}$ (R.T.), $25^{\circ} \mathrm{C}, 30{ }^{\circ} \mathrm{C}$ and $35^{\circ} \mathrm{C}$ at pH 7 for three hours. The beads were also tested at $\mathrm{pH}$ of $6.0,6.5$, 7.0, 7.5 and 8.0 at R.T. for three hours.

\section{RESULTS AND DISCUSSION}

\subsection{Effects of k-Carrageenan/Enzyme Solution Temperature}

As mentioned earlier the $\mathrm{k}$-carrageenan/enzyme solution was held at a temperature of $45^{\circ} \mathrm{C}$ and $50^{\circ} \mathrm{C}$. The temperature was varied to study the effect it had on bead production. During this process of incubation, no complication was experienced due to premature gelation in the pipes between the static mixer and pump 1 (Figure 1). Several batches were trialled at 45 ${ }^{\circ} \mathrm{C}$ and premature gelation occasionally occurred later on in the process. This posed a problem as it obstructed the flow between the static mixer and pump 1 and resulted in the formation of gels which did not have a distinct shape.

A simple test was done to estimate the drop in temperature between the static mixer and pump 1. A thermocouple was placed at the inlet of the static mixer and $\mathrm{k}$-Carrageenan/enzyme solution was fed to the static mixer at $50{ }^{\circ} \mathrm{C}$ with a flow rate of 40 or 20 $\mathrm{mL} / \mathrm{min}$. The temperature at the inlet of the static mixer was recorded. The temperature drop of the solutions for both the tested flow rates was $\pm 3^{\circ} \mathrm{C}$. This could be the reason for the premature gelation. Similar results were reported for a temperature range of $37^{\circ} \mathrm{C}-42^{\circ} \mathrm{C}$ and gelation with $1.5 \% \quad(\mathrm{w} / \mathrm{w}) \quad \mathrm{K}$-carrageenan in deionised water or $10 \mathrm{mM} \mathrm{CaCl}_{2}$ solution $[12,18]$.

Even though the pipe length between the static mixer and pump 1 was reduced and insulated as much as possible, there was a large temperature drop in the $\mathrm{K}$-carrageenan/enzyme solution at the slow flow rate used. It was observed that the solution being fed to the static mixer was almost stagnant in the pipes due to the low flow rate especially at $20 \mathrm{~mL} / \mathrm{min}$. This resulted in a slow "turn over" of k-carrageenan/enzyme solution. The $\mathrm{K}$-carrageenan in the pipes was replaced by "new" $\mathrm{K}$ carrageenan/enzyme solution at a low rate. The slow rate allowed the solution to lose heat thus explaining the reason for the occurrence of premature gelation after a certain period of time.

If no premature gelation occurred, the $\mathrm{K}$ carrageenan/enzyme solution would enter the static mixer at a temperature close to the gelation temperature. However gelation probably did not occur immediately due to the rapid cooling by the oil which was at R.T. Therefore the solution was still able to be emulsified. The gelation temperature is dependent on the concentration of $\mathrm{K}$-carrageenan and more importantly the cooling rate of the $\mathrm{k}$-carrageenan solution. An increase in concentration raises the gelation temperature but an increase in cooling rate decreases the temperature $[12,18]$. The rise in gelation temperature could denature $\beta$-galactosidase. Studies have shown that free $\beta$-galactosidase which is exposed to $50{ }^{\circ} \mathrm{C}$ for 25 minutes loses up to $50 \%$ of its activity. The enzyme can maintain more than half of its activity for 200 minutes at $45^{\circ} \mathrm{C}[19,20]$. In the present study, the $\mathrm{K}$-carrageenan/enzyme solution was held at $50{ }^{\circ} \mathrm{C}$ for approximately 5 to 10 minutes during the entire duration of the bead production process. The residual activity at 10 minutes would have been approx. 90\%, higher than what we have observed.

\subsection{Effects of $Q_{t}$ and $\varepsilon$ on Bead Size, Quality and Activity}

\subsubsection{Effect on Bead Size}

The effect of $Q_{t}$ on bead size is discussed firstly. $Q_{t}$ of 220 and $240 \mathrm{~mL} / \mathrm{min}$ are regarded as low flow rates while 420 and $440 \mathrm{~mL} / \mathrm{min}$ as high. The average bead sizes obtained from Figure (2A, B, C and D) were 19, 52,13 and $27 \mu \mathrm{m}$, respectively. The sizes obtained were smaller than the mesh size used to filter the encapsulated $\beta$-galactosidase. The reason is related to the experimental procedure involved. During vacuum filtration, the beads formed a layer of filter cake that prevented smaller size beads from passing through. Furthermore, filter paper was also used which acted as a support for the filter cake. Hence beads which were under $30 \mu \mathrm{m}$ could be obtained.

A comparison was done between the low and high flow rate results. There is a general trend that the bead size decreases with the increase in the flow rate. This is similar to other studies where the same outcome is obtained $[12,15] . Q_{t}$ has an effect on the mixing intensity and time. An increase in flow rate results in higher shear and elongation forces acting on the solution. This then induces an increase in dissipated energy which promotes droplet disintegration [12, 15]. The slight change in average bead size is also evident in the results reported in [12], where the bead mean diameter is not highly influenced by the range of flow rate tested at 200 to $400 \mathrm{~mL} / \mathrm{min}$. If the sizes obtained from $Q_{t}$ of 220 and $440 \mathrm{~mL} / \mathrm{min}$ are compared, an 

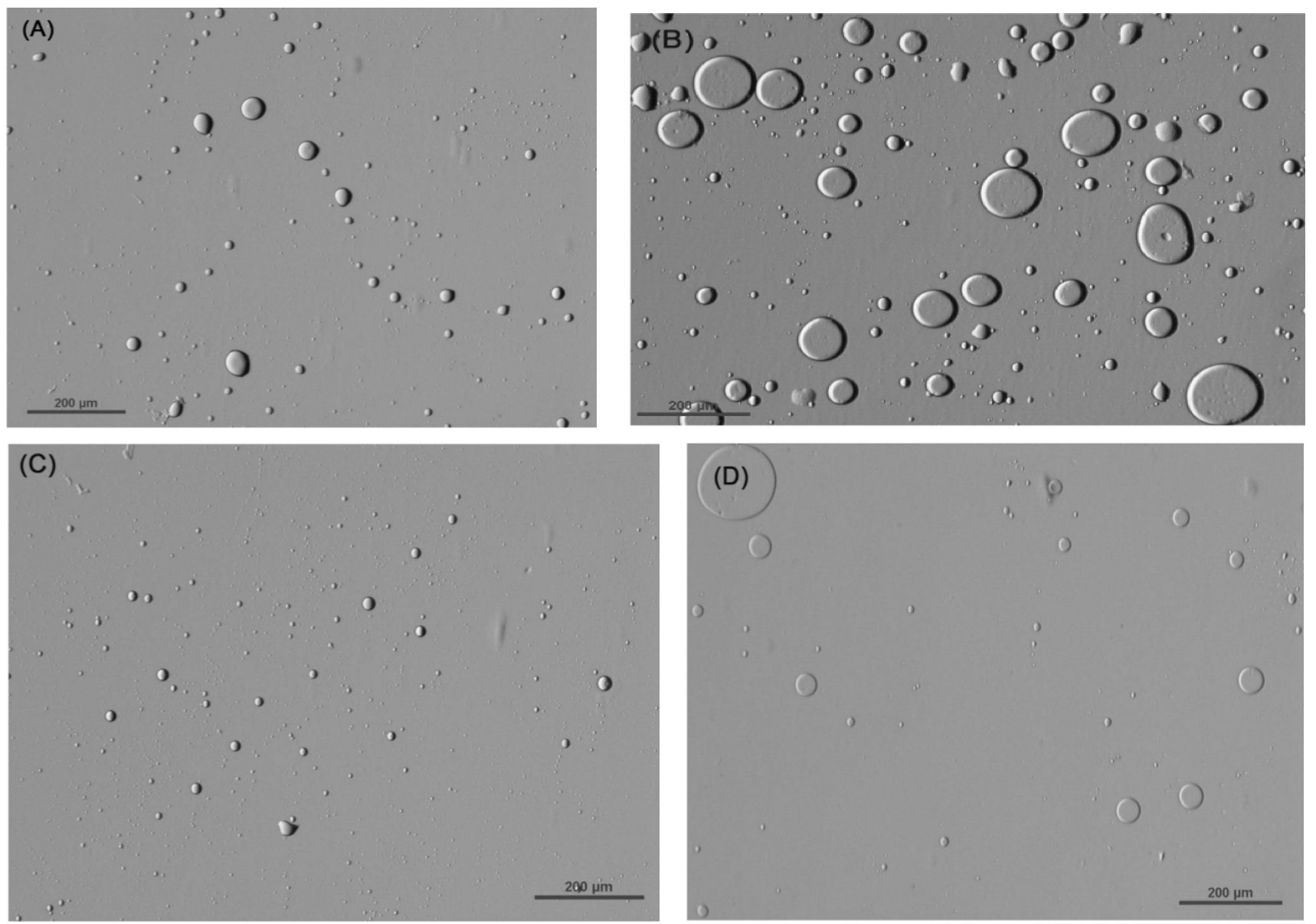

Figure 2: Optical microscope images of encapsulated $\beta$-galactosidase at different $Q_{t}$ of $($ A) $220 \mathrm{~mL} / \mathrm{min}$ (B) $240 \mathrm{~mL} / \mathrm{min}(\mathbf{C}) 420$ $\mathrm{mL} / \mathrm{min}$ and (D) $440 \mathrm{~mL} / \mathrm{min}$.

increase is seen instead of the expected decrease. The reason could be due to oil inclusions. This is explained later in the section.

The effect of $\mathrm{k}$-carrageenan to oil volumetric fraction $(\varepsilon)$ on bead size is studied as two groups which are the low and high flow rate. In the present study, $\varepsilon$ is increased from 0.1 to 0.2 at low rate flow rate (220 to $240 \mathrm{~mL} / \mathrm{min})$. Figure (2A and $\mathbf{B}$ ) show that the average size was increased by $33 \mu \mathrm{m}$. This is probably due to the coalescence between the emulsified droplets which occurs at low flow rate as mentioned in the literature [15]. It was also showed that in the coalescence occurred in most of the samples studied at $\varepsilon$ of 0.1 [12]. Hence higher coalescence would be observed at 0.2 . The increase in coalescence rate is due to the increase of $\mathrm{K}$-carrageenan/enzyme solution to oil. This results in a higher concentration of K-carrageenan/enzyme solution which raises the probability of the molecules colliding with each other [21].

At high flow rate, the rate of coalescence between the emulsified droplets should not increase as $\varepsilon$ increases [15]. Hence a similar size was expected but this is not the case as the results show an increase in bead size. The high flow rate group showed an increase of $14 \mu \mathrm{m}$ (Figure $\mathbf{2 C}$ and D) as $\varepsilon$ was increased from 0.05 to 0.1 (420 to $440 \mathrm{~mL} / \mathrm{min}$ ). A possible explanation could be oil inclusions in beads tend to happen at high flow rate [12] due to the increase in inertial forces acting on the dispersed droplets. The oil inclusion could increase the bead size as well at flow rates of 220 and $440 \mathrm{~mL} / \mathrm{min}$.

\subsubsection{Effect on Bead Quality}

The effects of $Q_{t}$ and $\varepsilon$ on bead quality were also studied. The overall quality of beads produced was gauged by the weight percentage of beads located below the oil layer labelled as $\mathrm{WB}_{\text {top }}$ (Figure 3 ). The yield percentage is defined as the weight of encapsulated $\beta$-galactosidase recovered over $100 \mathrm{~g}$ of $\mathrm{K}$-carrageenan/enzyme solution. It was expected that all the beads would settle at the bottom of the container due to the difference in density but this was not observed in the present study. 


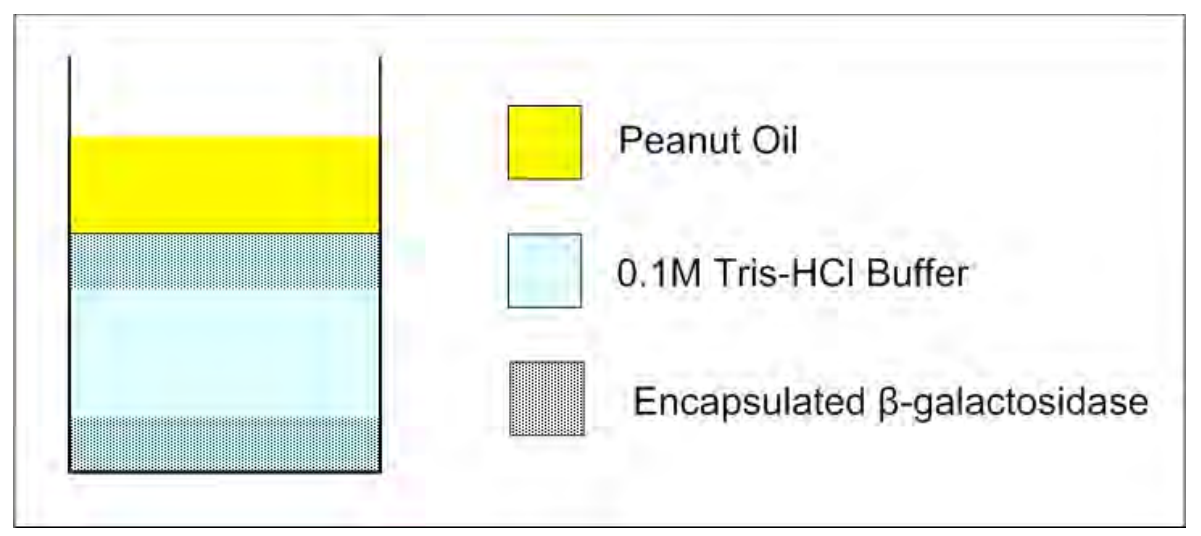

Figure 3: Free $\beta$-galactosidase from Kluyveromyces fragilis was tested at $\mathrm{pH} 7.2$ with ONPG substrate for thermal stability [Santos, et al, 1998].

The schematic shown in Figure $\mathbf{3}$ was observed for all $Q_{t}$ tested. The encapsulated beads located at the bottom could be regarded as good quality beads due to its translucent physical appearance compared to the beads beneath the oil layer which had a shade of pale yellow. The settled beads could also be dispersed easily if agitated but the beads under the oil layer remained coalesced. This suggests that the settled beads are discrete. A possible reason for the "floating" beads is oil inclusions in the bead. The oil traces would reduce the density of the beads thus allowing them to float just beneath the oil layer. Another possibility is the entrapment of oil between the aggregated beads which would also reduce the beads' bulk density and cause a similar outcome as mentioned before. This may also further strengthen the aggregation between the oil and $\mathrm{k}$-carrageenan molecules.

The main reason for the occurrence of the two kcarrageenan beads layer is that the static mixer used in the present study had insufficient elements (four elements were used) to provide complete or good emulsification. The number of mixing elements determines the residence time of the solution in the mixer to form homogenised beads [12, 15].

The $W B_{\text {top }}$ obtained for beads produced with $Q_{t}$ of $220,240,420$ and $440 \mathrm{~mL} / \mathrm{min}$ were $22,88,35$ and $29 \%$. The effect of $Q_{t}$ on bead quality is compared between $Q_{t}$ of 220 and $440 \mathrm{~mL} / \mathrm{min}$ as they have the same $\varepsilon$. The yield for beads made from $Q_{t}$ of 220 and $440 \mathrm{~mL} / \mathrm{min}$ were $45.6 \%$ and $46.6 \%$ respectively. The weight yield from a similar study was 58 to $66 \%$ [12]. The $W B_{\text {top }}$ for $Q_{t}$ of $220 \mathrm{~mL} / \mathrm{min}$ was $7 \%$ lower than that for $440 \mathrm{~mL} / \mathrm{min}$ suggesting better quality beads at $Q_{t}$ of $220 \mathrm{~mL} / \mathrm{min}$. Although a high flow rate could provide more energy and also could promote oil inclusion [12, 13]. The oil inclusions would cause an increase in
$\mathrm{WB}_{\text {top. }}$ However at a lower flow rate, the $\mathrm{K}$ carrageenan/enzyme solution and oil would have more mixing/residence time in the static mixer. This results in a better emulsification thus reducing $\mathrm{WB}_{\text {top }}$.

The change of $\varepsilon$ from 0.1 to 0.2 at low flow rate showed a $\mathrm{WB}_{\text {top }}$ increase of $66 \%$. The huge difference is possibly due to the increase in bead aggregation as concentration of $\mathrm{k}$-carrageenan/enzyme solution increases. Therefore more oil is entrapped between the beads which cause the increase of $W_{\text {top. }}$

At high flow rates there was a decrease of $6 \%$ in $W B_{\text {top }}$ when $\varepsilon$ was changed from 0.05 to 0.1 . It was expected that the $W B_{\text {top }}$ for $Q_{t}$ of $440 \mathrm{~mL} / \mathrm{min}(\varepsilon$ of 0.1 ) would be higher than $420 \mathrm{~mL} / \mathrm{min}(\varepsilon$ of 0.05$)$ due to the higher possibility of aggregation between the beads. This was not observed in our result and could be explained as the degree of $\varepsilon$ applied may not have caused significant bead aggregation difference. The dominating factor on $\mathrm{WB}_{\text {top }}$ could be due to oil inclusion which is unpredictable in the present study. This could result in the unexpected difference of $6 \%$ in $\mathrm{WB}_{\text {top }}$.

\subsubsection{Effect on Bead Activity}

The beads obtained from different $Q_{t}$ and $\varepsilon$, were tested for three hours with ONPG substrate. The results are shown in Figure 4. The highest activity was achieved with beads made from $Q_{t}$ of $220 \mathrm{~mL} / \mathrm{min}$. Beads made from $Q_{t}$ of 420 and $440 \mathrm{~mL} / \mathrm{min}$ showed a 26.73 and $17.21 \%$ activity drop respectively. The lowest activity of $57.35 \%$ was obtained with beads made from $Q_{t}$ of $240 \mathrm{~mL} / \mathrm{min}$. The lower activity drop seen at the high flow rates compared to $Q_{t}$ of 220 $\mathrm{mL} / \mathrm{min}$ could be due to the oil inclusions in the beads. The oil might interfere with the internal diffusion of the product and substrate especially later in the experiment. This may cause a build up of products in 


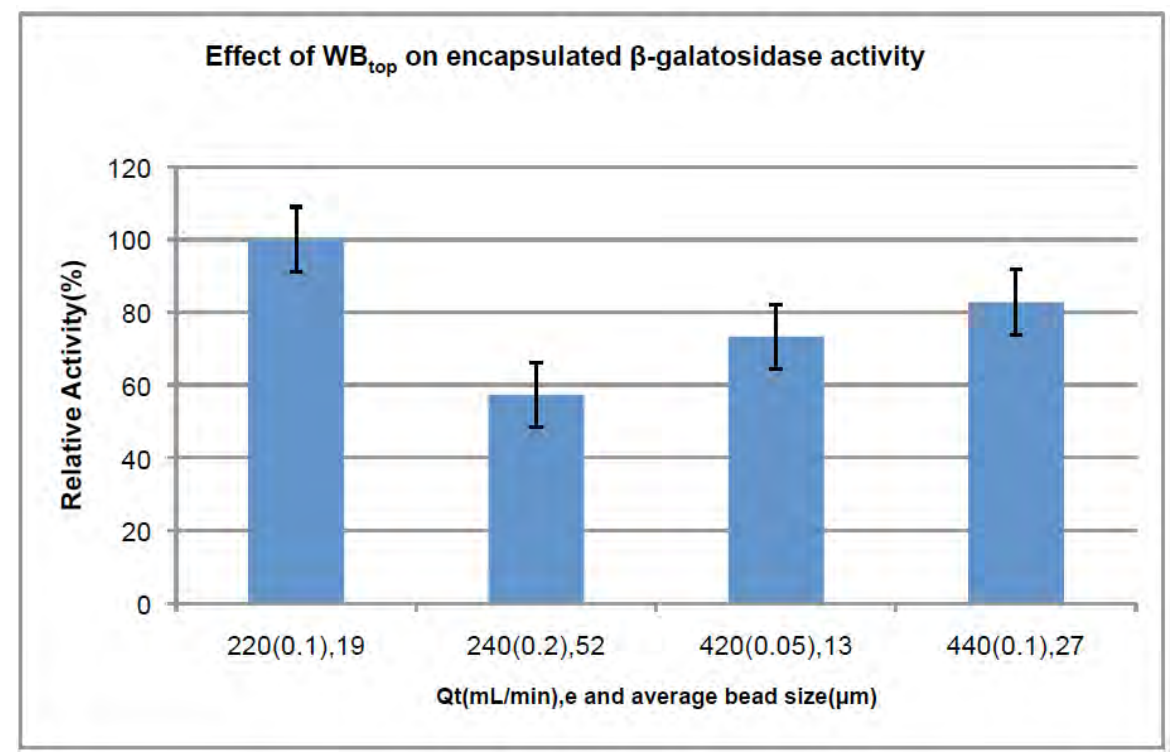

Figure 4: A schematic of encapsulated $\beta$-galactosidase collected in a liquid-liquid emulsion. The beads were formed under the peanut oil layer and settled at the base of the receiving container.

the beads as the reaction progresses. The hydrolysis process would eventually be affected due to product inhibition by galactose. The low activity from beads made with $Q_{t}$ of $240 \mathrm{~mL} / \mathrm{min}$ is related to $\varepsilon$ and is discussed in the following paragraph.

The increase of $\varepsilon$ from 0.1 to 0.2 in the low flow rate group showed a decrease in activity. The reason could be due to the high aggregation between the beads which reduces the amount of surface area for the substrate to diffuse into the beads. The remaining traces of oil between the beads that were not washed off would also increase the external diffusion resistance and hinder the substrate diffusion into the beads. The presence of oil traces in the enzyme activity test is due to the experimental method as described. The beads retrieved from the top were rinsed a couple times with $0.1 \mathrm{M}$ Tris- $\mathrm{HCl}$ buffer. It was then mixed with the bottom layer beads. The bead were then chitosan

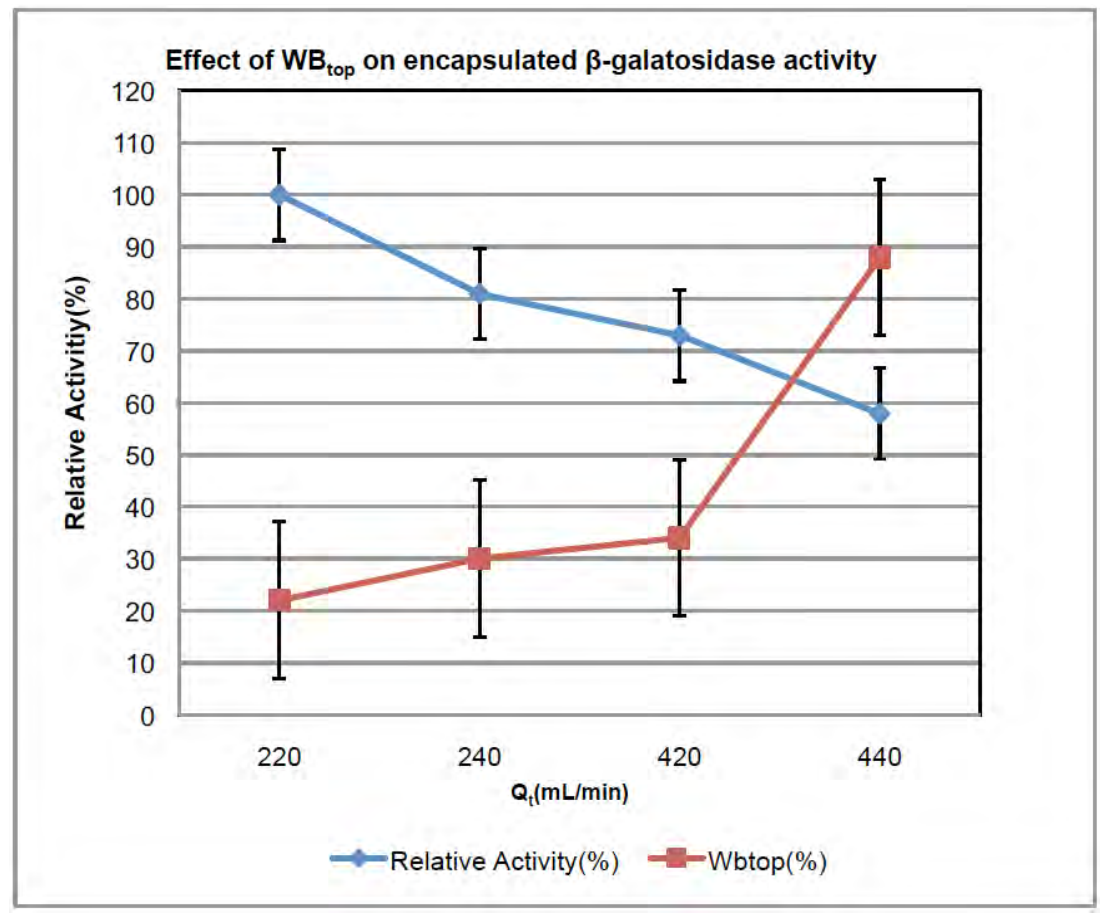

Figure 5: Comparison between maximum bead activities and $\mathrm{WB}_{\text {top }}$ at flow rates of of $220,240,420$ and $440 \mathrm{~mL} / \mathrm{min}$ and $\varepsilon$ of $0.1,0.2,0.05$ and 0.1 . 
coated and used for activity testing. The beads prepared at flow rate of $240 \mathrm{~mL} / \mathrm{min}$ had the highest $W B_{\text {top }}$ of $88 \%$ and also the lowest activity of $57.35 \%$.

The increase of $\varepsilon$ from 0.05 to 0.1 in the high flow rate group showed an increase in activity. The reason is again related to the quality of the beads produced. The beads made from $Q_{t}$ of $420 \mathrm{~mL} / \mathrm{min}$ showed a higher $W B_{\text {top }}$ compared to $Q_{t}$ of $440 \mathrm{~mL} / \mathrm{min}$. This was translated to the bead activity which showed that the activity was higher for beads made with $Q_{t}$ of 440 $\mathrm{mL} / \mathrm{min}$.

It was also observed that as $\mathrm{WB}_{\text {top }}$ increases the relative activity decreases (Figure 5). This further indicates that the activity is affected by the quality of the beads. No distinctive trend between the average bead size and activity could be concluded from the results. The reason may be due to the unquantifiable external diffusion resistance caused by uneven chitosan coating, clumping of beads and traces of oil on the beads. Overall, there is no direct influence of $Q_{t}$ and $\varepsilon$ on the bead production process.

\subsection{Encapsulated $\beta$-Galactosidase Morphology}

The beads were viewed under a SEM to study its morphology. The images confirmed that the beads are approximately spherical in shape. Figures (6A and 6B) show beads with rough surfaces compared to the bead in Figure 6C which was not submerged in chitosan. Hence the rough surface observed is due to the successful coating of the beads with chitosan. A similar image was presented in the literature [22].

\subsection{Operational Stability Test}

The encapsulated $\beta$-galactosidase obtained at $Q_{t}$ of $220 \mathrm{~mL} / \mathrm{min}$ was tested with ONPG substrate to demonstrate its reusability. The beads retained $52.65 \%$ of its initial activity after four repeated cycles as shown in Figure 7. This result is similar to those reported in
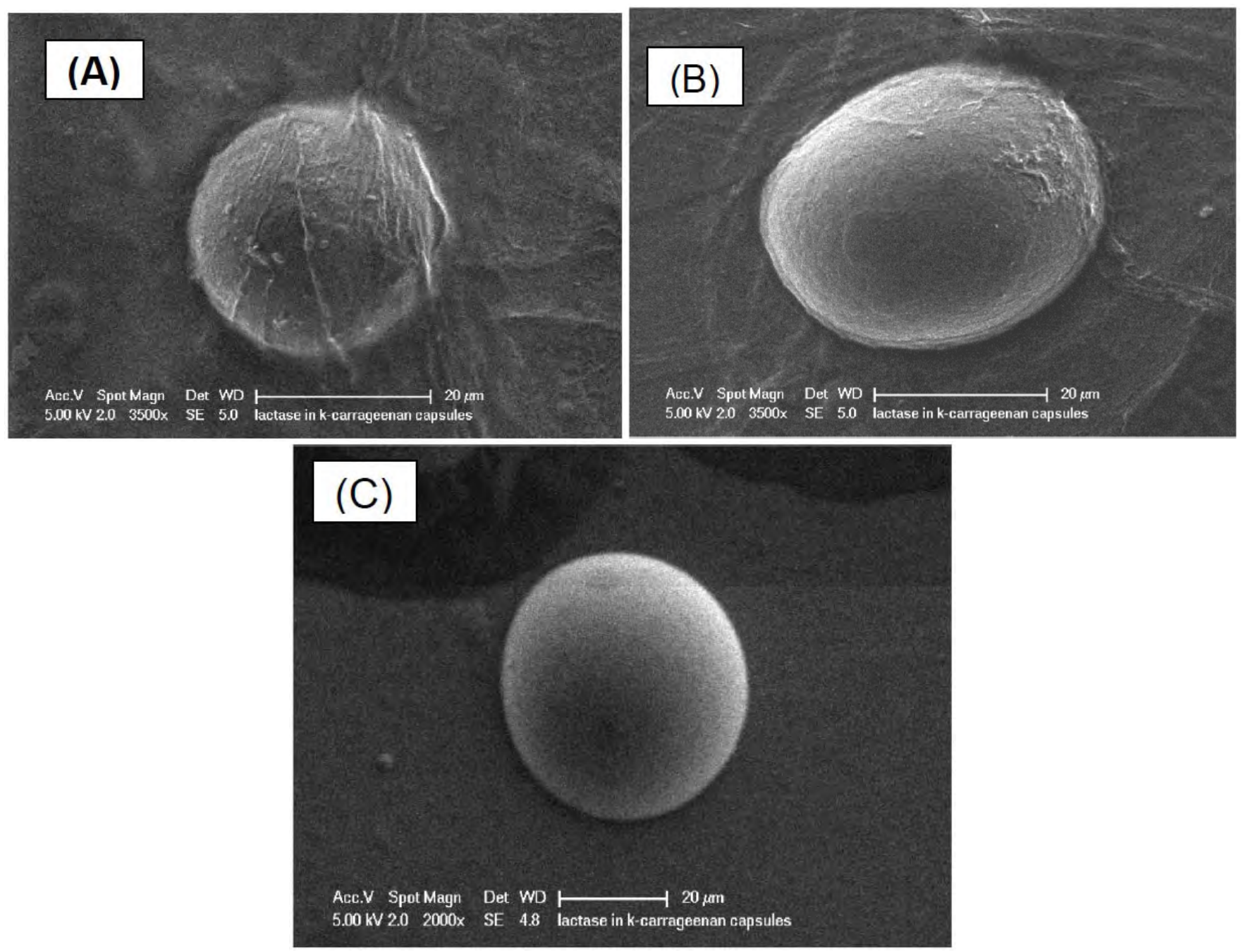

Figure 6: Effect of $W^{\text {top }}$ on bead activity. The increase in $W B_{\text {top }}$ resulted in a decrease in relative bead activity. 


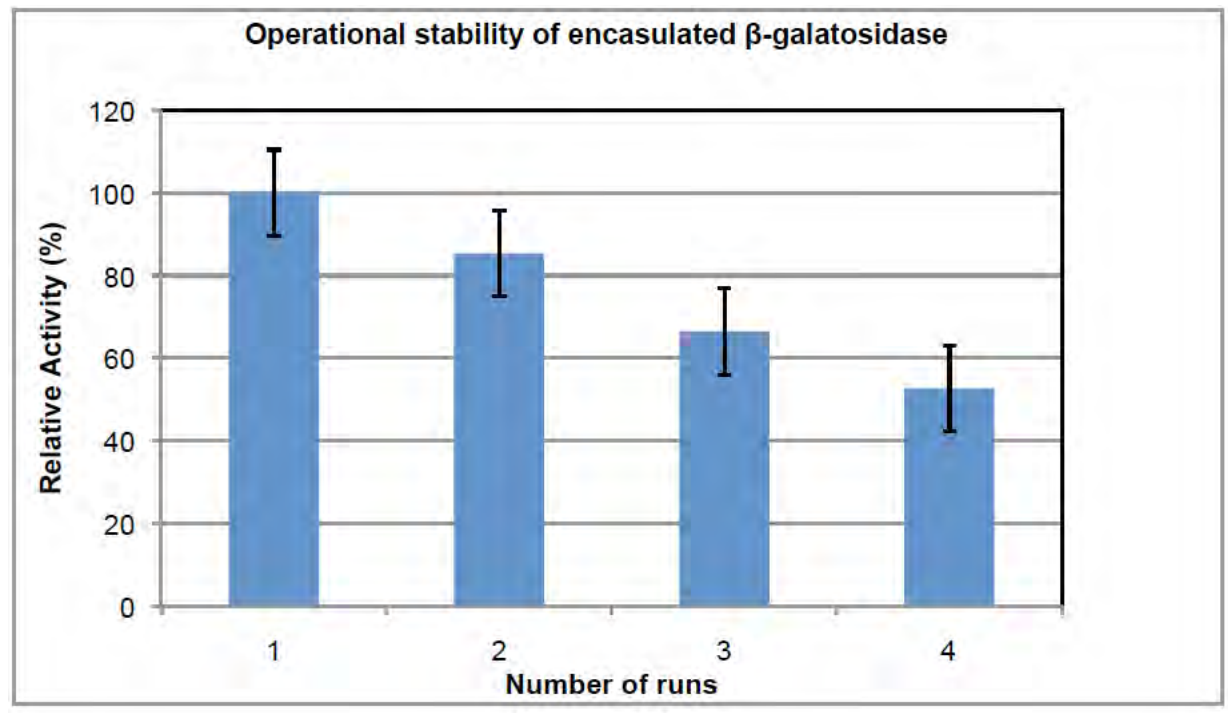

Figure 7: (A-C): SEM images of encapsulated $\beta$-galactosidase at $Q_{t}$ of $(\mathbf{A}) 220 \mathrm{~mL} / \mathrm{min}(\mathbf{B}) 440 \mathrm{~mL} / \mathrm{min}$ and $(\mathbf{C}) 220 \mathrm{~mL} / \mathrm{min}$ without chitosan coating.

the literature [12, 13]. The beads showed low reusability even after coating with chitosan, similar to those obtained in previous work [12]. This may have been caused by the uneven chitosan coating on the bead that would have lowered the retention capability.

\subsection{Storage Stability Test}

The encapsulated $\beta$-galactosidase obtained, at $\mathrm{Q}_{\mathrm{t}}$ of $440 \mathrm{~mL} / \mathrm{min}$, was tested with ONPG substrate to demonstrate its storage stability. The beads were stable for up to one week. It retained $57.17 \%$ of its initial activity (100\%) after three weeks of storage as shown in Figure 8 . The beads were stored in distilled water (without any buffer) to reduce leaching during storage (following the method in [23] for encapsulation of lipase in K-carrageenan), which showed higher activity retention of $50 \%$ for four days. Although the storage stability does not have any direct effect on the bead production process, it is important to understand the performance of the beads upon storage.

\subsection{Long Lactose Hydrolysis Test}

The encapsulated $\beta$-galactosidase was tested with $5 \%(\mathrm{w} / \mathrm{v})$ lactose solution at R.T. and $4^{\circ} \mathrm{C}$ for six days. The result from the R.T test shows $8.06 \times 10^{3} \mathrm{LAU}$ after three hours. This translated to $1 \%$ of lactose

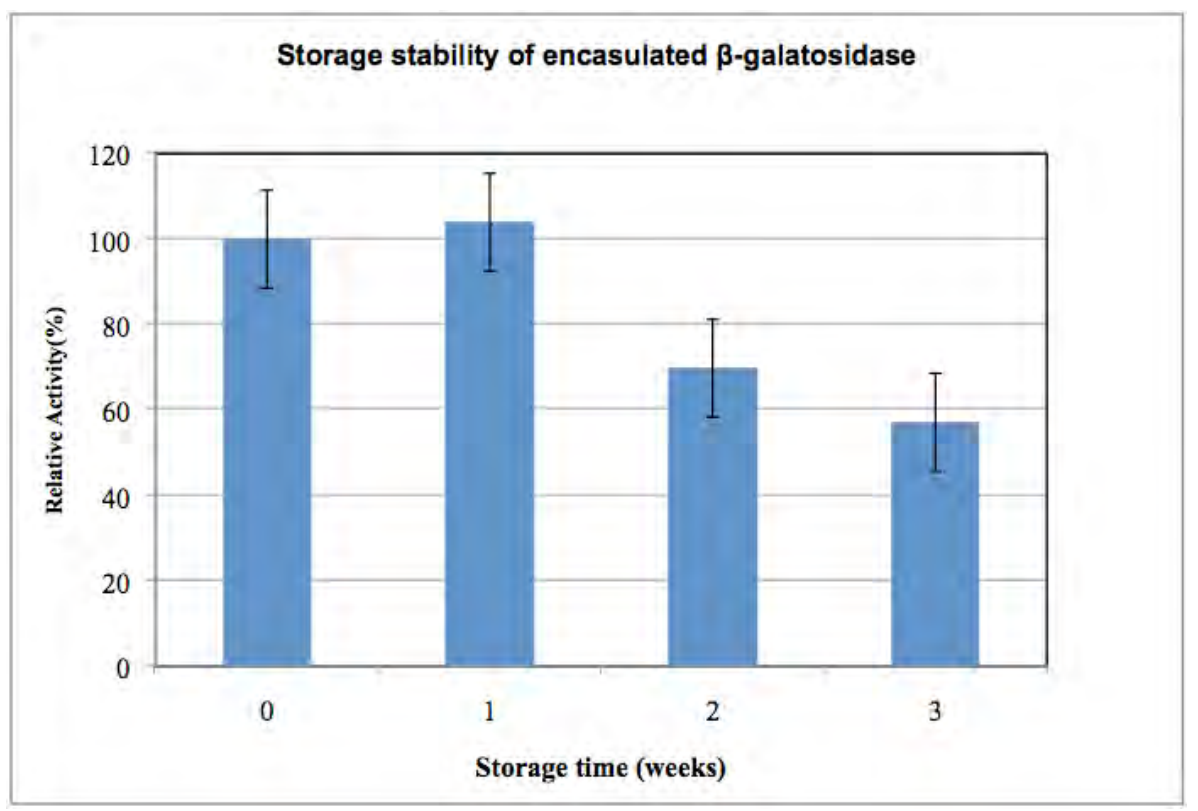

Figure 8: Repeatability of encapsulated $\beta$-galactosidase tested at $\mathrm{pH} 7,21^{\circ} \mathrm{C}$ with $3.67 \mathrm{mM}$ ONPG substrate. 


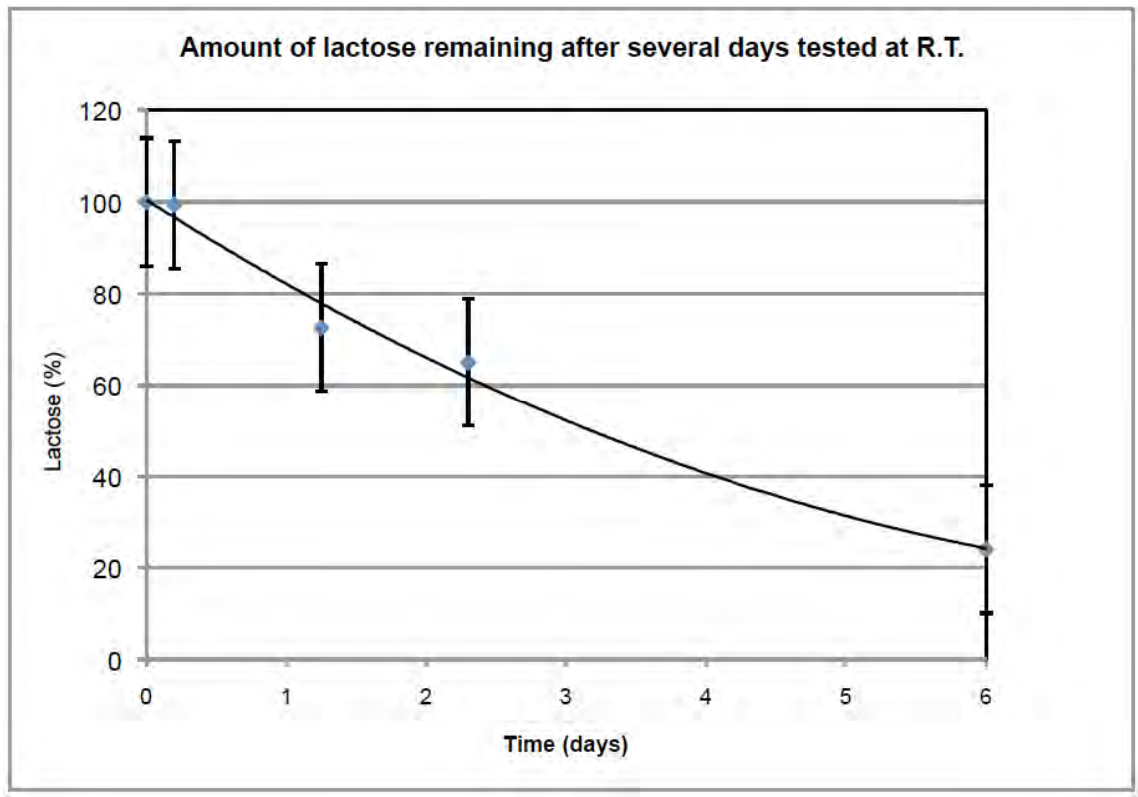

Figure 9: Storage stability of encapsulated $\beta$-galactosidase at $\mathrm{pH} 7,21^{\circ} \mathrm{C}$ with $3.67 \mathrm{mM}$ ONPG.

conversion. However $76.74 \%$ lactose conversion or $1.23 \times 10^{2}$ LAU was achieved over six days as seen in Figure 9.

The experiment carried out at $4^{\circ} \mathrm{C}$ resulted in a $0.2 \%$ lactose conversion after three hours. The final conversion achieved after six days was only $2 \%$ or $3.33 \times 10^{4}$ LAU as shown in Figure 10. A chart from a section in the Food Science and Technology showed that almost $20 \%$ lactose hydrolysis in milk is achieved at $20{ }^{\circ} \mathrm{C}$ and $7 \%$ at $5{ }^{\circ} \mathrm{C}$ after 18 hours [24]. This finding is used to compare with the result obtained from the first three hours. The drop of $65 \%$ lactose hydrolysis is close to the $80 \%$ drop obtained in the present study. A possible reason for the low conversion after six days at $4^{\circ} \mathrm{C}$ is because of the experimental method. The solution was not stirred after the first three hours. This would affect the diffusion of the substrate and products going into and out of the beads.

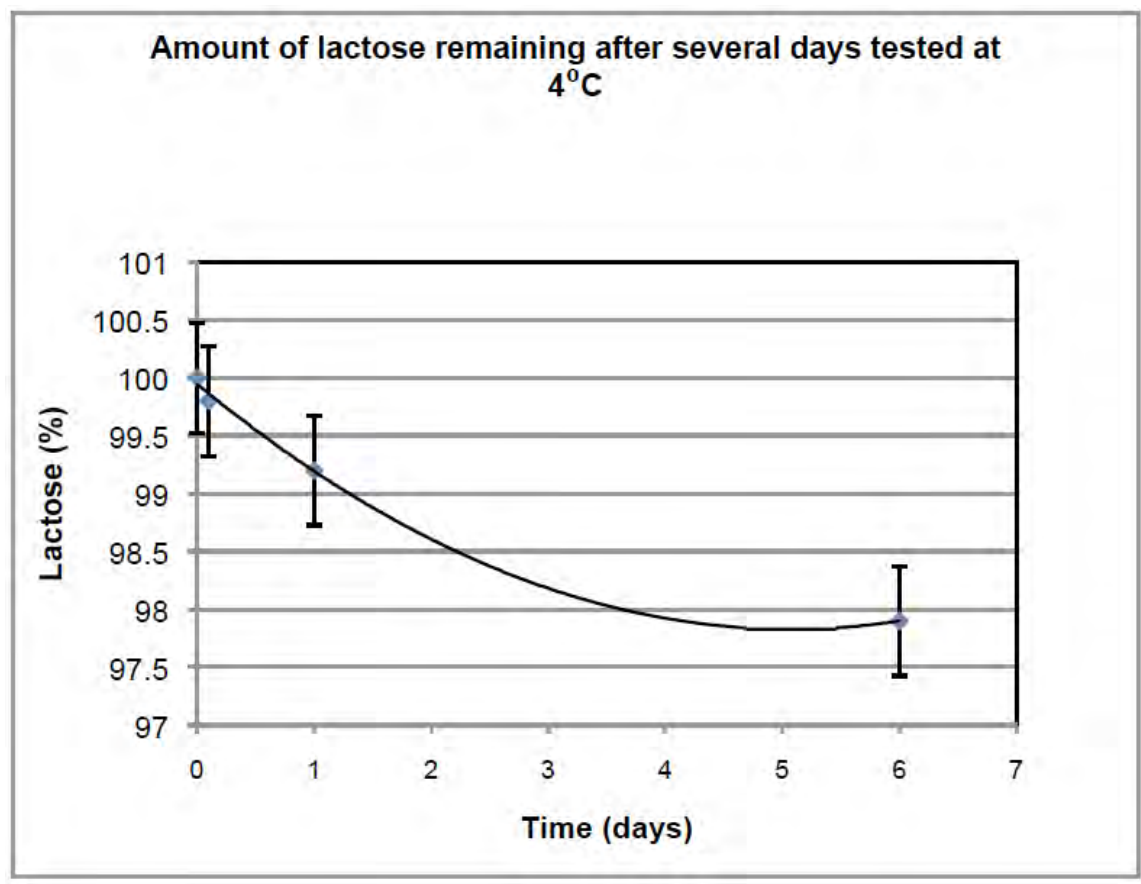

Figure 10: Lactose (\%) in residual solution over a period of six days. Beads (prepared at $\mathrm{Q}_{\mathrm{t}}$ of $220 \mathrm{~mL} / \mathrm{min}$ ) were tested in $5 \%$ (w/v) lactose solution, at $\mathrm{pH} 7$ and $21^{\circ} \mathrm{C}$. 


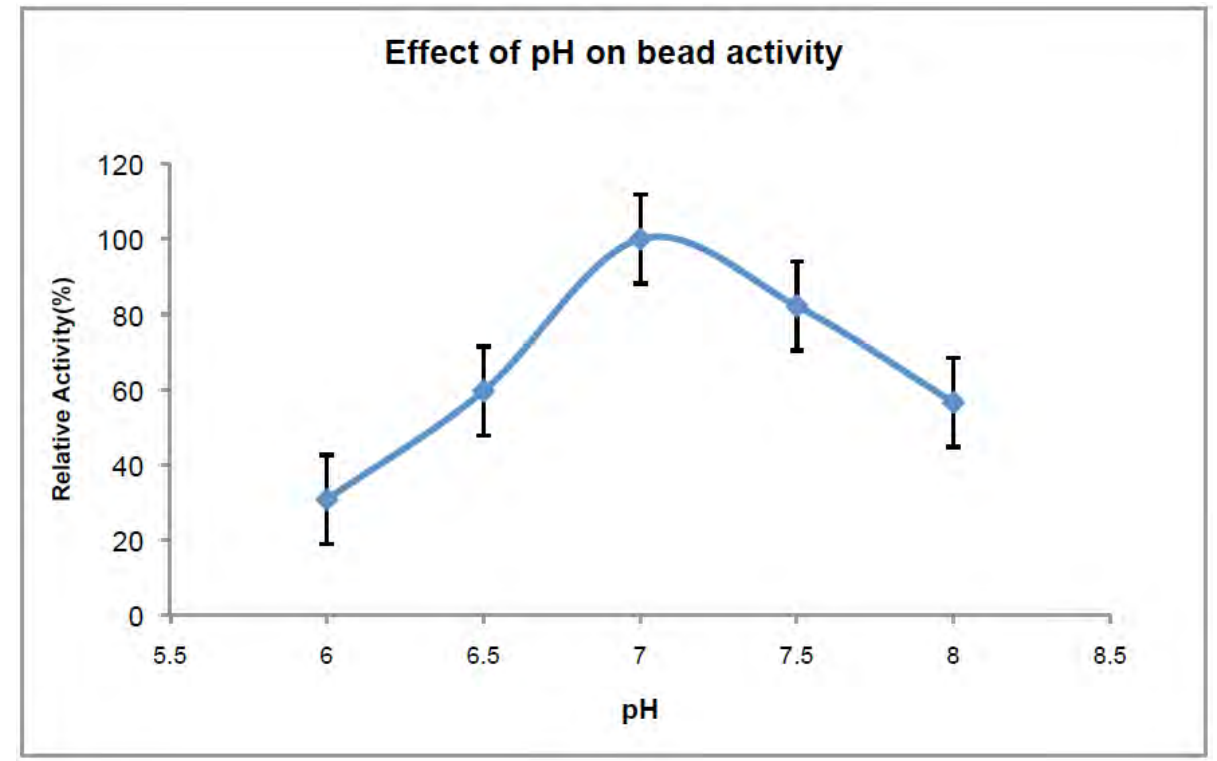

Figure 11: Lactose (\%) remaining in solution over six days. Beads (made with $\mathrm{Q}_{\mathrm{t}}$ of $220 \mathrm{~mL} / \mathrm{min}$ ) were tested in $5 \%(\mathrm{w} / \mathrm{v}$ ) lactose solution, $\mathrm{pH} 7$ at $4^{\circ} \mathrm{C} .97 .92 \%$ lactose remained after six days.

The optimum conditions were obtained with beads formulated at $Q_{t}$ of $440 \mathrm{~mL} / \mathrm{min}$. They were tested with ONPG substrate for three hours. The highest activity was obtained at $\mathrm{pH}$ of 7 as shown in Figure 11. It is comparable to that of free $\beta$-galactosidase from $\mathrm{K}$. Lactis [7]. Other studies on encapsulation of $\beta$ galactosidase also showed only a slight change in the optimum $\mathrm{pH}[25,26]$. A possible reason is that the enzyme is immobilised using a physical method in the present study. Therefore the ionisable groups in the active site of $\beta$-galactosidase are more likely to remain the same compared to methods which require covalent bonding or polymerisation. The beads showed higher activity in alkali condition compared to acidic condition. This trend is similar to those of the other studies [7, 26].

\section{CONCLUSIONS}

The encapsulation of $\beta$-galactosidase was successfully carried out by emulsifying oil and $\mathrm{K}$ carrageenan with a static mixer device. This method of immobilisation has produced smaller beads with size less than $100 \mu \mathrm{m}$ with added advantage of continuous processing option. The main factors that affected the size were: the total flow rate through the static mixer $\left(Q_{\mathrm{t}}\right.$, in the range $\left.220-440 \mathrm{ml} / \mathrm{min}\right)$ and $\mathrm{k}$-carrageenan to oil volumetric fraction $(\varepsilon$, in the range $0.05-0.2)$. The average bead sizes obtained were in the range of 19$52 \mu \mathrm{m}$, with smaller sizes obtained with an increase of $\mathrm{Q}_{\mathrm{t}}$.

The bead performance was tested using lactose and 2-nitrophenyl- $\beta$-galactopyranoside (ONPG) and the optimum conditions of $\mathrm{pH}$ (a value of, similar to that of free enzyme) and temperature (of $37^{\circ} \mathrm{C}$ ) were determined. At the optimum conditions the encapsulated $\beta$-galactosidase, tested with $5 \%(\mathrm{w} / \mathrm{v})$ lactose solution, was able to convert $76.47 \%$ of lactose after six days. The stability of the encapsulated enzyme was similar to those in the literature (retained 57.17\% of its initial activity after 3 weeks) and can be used a few times without significant loss of activity. Overall these findings contribute to the further understanding of the encapsulation technique and demonstrates the potential of using $\mathrm{k}$-carrageenan as an encapsulation material for $\beta$-galactosidase.

\section{ACKNOWLEDGEMENTS}

The authors would like to thank the University of Auckland, New Zealand, for funding this research.

\section{REFERENCES}

[1] Paige DM. Lactose intolerance. In: Caballero B, Allen L, Prentice A, editors. Encyclopedia of Human Nutrition. $2^{\text {nd }}$ ed. Oxford: Elsevier 2005.

[2] Novalin S, Neuhaus W, Kulbe KD. A new innovative process to produce lactose-reduced skim milk. J Biotechnol 2005; 119(2): 212-18. http://dx.doi.org/10.1016/j.jbiotec.2005.03.018

[3] Ladero M, Santos A, Garcia-Ochoa F. Kinetic modeling of lactose hydrolysis with an immobilized $\beta$-galactosidase from Kluyveromyces fragilis. Enz Microb Technol 2000; 27: 58392.

http://dx.doi.org/10.1016/S0141-0229(00)00244-1

[4] Mammarella EJ, Rubiolo AC. Study of the deactivation of $\beta$ galactosidase entrapped in alginate-carrageenan gels. J Mol Cat B Enzymatic 2005; 34: 7-13. http://dx.doi.org.ezproxy.uaeu.ac.ae/10.1016/i.molcatb.2005. $\underline{04.007}$ 
[5] Li X, Zhou QZK, Chen XD. Pilot-scale lactose hydrolysis using beta-galactosidase immobilized on cotton fabric. Chem Eng Proc 2007; 46: 497-500. http://dx.doi.org.ezproxy.uaeu.ac.ae/10.1016/cep.2006.02.01 1

[6] Cheetham PSJ. Principles of industrial biocatalysis and bioprocessing. In: Wiseman A., editor. Handbook of enzyme biotechnology, 3rd ed. UK: Ellis Horwood 1995.

[7] Zhou QZK, Chen XD. Effects of temperature and $\mathrm{pH}$ on the catalytic activity of the immobilized b-galactosidase from Kluyveromyces lactis. Biochem Eng J 2001; 9: 33-40. http://dx.doi.org.ezproxy.uaeu.ac.ae/10.1016/S1369703X(01)00118-8

[8] Lu L, Zhao M, Wang Y. Immobilization of laccase by alginate-chitosan microcapsules and its use in dye decolorization. World J Microbiol Biotechnol 2007; 23: 15966. http://dx.doi.org/10.1007/s11274-006-9205-6

[9] Flickinger CM, Drew, SW. Microencapsulation, in Encyclopedia of Bioprocess Technology - Fermentation, Biocatalysis and Bioseparation. New York: Wiley 1999.

[10] Betigeri SS, Neau SH. Immobilization of lipase using hydrophilic polymers in the form of hydrogel beads. Biomaterials 2002; 23: 3627-36. http://dx.doi.org/10.1016/S0142-9612(02)00095-9

[11] Van De Velde F, Lourenco ND, Pinheiro HM. and Bakker, M. Carrageenan: A Food-Grade and Biocompatible Support for Immobilisation Techniques. Adv Syn Catal 2002; 344: 81535. http://dx.doi.org/10.1002/1615-4169(200209)344:8<815::AIDADSC815>3.0.CO;2-H

[12] Reis CP, Neufeld RJ, Vilela S, Ribeiro A, Oacutenio J, Veiga F. Review and current status of emulsion/dispersion technology using an internal gelation process for the design of alginate particles. J Microencapsulation 2006; 23: 245-57. http://dx.doi.org/10.1080/02652040500286086

[13] Belyaeva E, Valle DD, Poncelet D. Immobilization of $\alpha$ chymotrypsin in k-carrageenan beads prepared with the static mixer. Enz Microbial Technol 2004a; 34: 108-13. http://dx.doi.org.ezproxy.uaeu.ac.ae/10.1016/enzictech.2003. $\underline{07.009}$

[14] Belyaeva E, Valle DD, Neufeld RJ, Poncelet D. New approach to the formulation of hydrogel beads by emulsification/thermal gelation using a static mixer. Chem Eng Sci 2004b; 59: 2913-20.

http://dx.doi.org.ezproxy.uaeu.ac.ae/10.1016/ces.2004.04.01 $\underline{0}$

[15] Decamps C, Norton S, Poncelet D, Neufeld RJ. Continuous pilot plant-scale immobilization of yeast in k-carrageenan gel beads. AIChE J 2004; 50: 1599-605. http://dx.doi.org/10.1002/aic.10143

[16] Raymond MC, Neufeld RJ, Poncelet D. Encapsulation of brewers yeast in chitosan coated carrageenan microspheres by emulsification/thermal gelation. Artificial Cells, Blood Substitutes, and Immobilization. Biotechnol 2004; 32: 27591.

http://dx.doi.org/10.1081/BIO-120037832
[17] Yi Y, Neufeld RJ. Immobilization of cells in polysaccharide Gels, in Dumitriu S, editor. Polysaccharides: Structual diversity and functional versatility. New York: Marcel Dekker 1998.

[18] lijima M, Hatakeyama T, Takahashi M, Hatakeyama H. Effect of thermal history on kappa-carrageenan hydrogelation by differential scanning calorimetry. Thermochimica Acta 2007; 452: $53-8$

http://dx.doi.org.ezproxy.uaeu.ac.ae/10.1016/j.tca.2006.10.0 $\underline{19}$

[19] Santos A, Ladero M, Garcia-Ochoa F. Kinetic modeling of lactose hydrolysis by a $\beta$-Galactosidase from Kluyveromices Fragilis. Enz Microb Technol 1998; 22: 558-67. http://dx.doi.org.ezproxy.uaeu.ac.ae/10.1016/S01410229(97)00236-6

[20] Matioli G, Moraes FF, Zanin GM. Hydrolysis of lactose by $\beta$ galactosidase from Kluyveromyces fragilis:characterization of the enzyme. Acta Scientiarium 2001; 23: 655-59.

[21] McClements DJ. Emulsion formation, in Food emulsions: Principles, Practices and Techniques. New York: CRC 2005.

[22] Ribeiro AJ, Silva C, Ferreira D, Veiga F. Chitosan-reinforced alginate microspheres obtained through the emulsification/internal gelation technique. Eur J Pharm Sci 2005; 25: 31-40.

http://dx.doi.org.ezproxy.uaeu.ac.ae/10.1016/j.ejps.2005.01.0 $\underline{16}$

[23] Desai PD, Dave AM, Devi S. Entrapment of lipase into $\kappa$-carrageenan beads and its use in hydrolysis of olive oil in biphasic system. J Mol Cat B Enzymatic 2004; 31: 143-50. http://dx.doi.org.ezproxy.uaeu.ac.ae/10.1016/j.molcatb.2004. $\underline{08.004}$

[24] Rodriguez-Nogales JM, Lopez AD. A novel approach to develop $\beta$-galactosidase entrapped in liposomes in order to prevent an immediate hydrolysis of lactose in milk. Intl Dairy J 2006; 16: 354-60.

http://dx.doi.org.ezproxy.uaeu.ac.ae/10.1016/.i.idairyj.2005.05 .007

[25] Wadiak DT, Carbonell RG. Kinetic Behaviour of microencapsulated $\beta$-galactosidase. Biotechnol Bioeng 1975; 17: 1157-81.

http://dx.doi.org/10.1002/bit.260170806

[26] Rogalski J, Dawidowiez A, Leonowiez A. Lactose hydrolysis in milk by immobilizard $\beta$-galactosidase. J Mol Cat 1994; 93: 233-45.

http://dx.doi.org.ezproxy.uaeu.ac.ae/10.1016/03045102(94)00092-1

[27] Bayramoglu G, Yagmur T, Yakup A. Immobilization of $\beta$ galactosidase onto magnetic poly(GMA-MMA) beads for hydrolysis of lactose in bed reactor. Catalysis Communications 2006; 8: 1094-101.

http://dx.doi.org.ezproxy.uaeu.ac.ae/10.1016/j.catcom.2006.1 $\underline{0.029}$

\section{DOl: http://dx.doi.org/10.6000/1927-3037/2012.01.03.07}

(c) 2012 Tan et al.; Licensee Lifescience Global.

This is an open access article licensed under the terms of the Creative Commons Attribution Non-Commercial License (http://creativecommons.org/licenses/by-nc/3.0/) which permits unrestricted, non-commercial use, distribution and reproduction in any medium, provided the work is properly cited. 